\title{
Equus (Sussemionus) ovodovi Eisenmann et Vasiliev, 2011 from the Late Pleistocene of Western Siberia
}

\author{
Natalya A. Plasteeva*, Sergey K. Vasiliev \& Pavel A. Kosintsev
}

\begin{abstract}
Small equid remains are frequent in the Late Pleistocene deposits in the southern part of Western Siberia. Re-examination of fossil material previously attributed to E. hydruntinus or E. hemionus revealed its attribution to E. ovodovi. Morphologically it is characterized by slender third metapodials, short protocone on the upper teeth, V-shaped lingual valley, and occurrence of isolated stylids on the lower teeth. In Late Pleistocene E. ovodovi was widespread in the southern part of Western Siberia. Its remains are reported from Priobskoye Plateau, Altai, and Kuznetsk Alatau. To the east the range reached at least the Yenisei River. Radiocarbon dates suggest E. ovodovi inhabited the area until the end of the Kargin interstadial (MIS 3).
\end{abstract}

KEY WORDS. Equus ovodovi, Equidae, Pleistocene, Western Siberia, morphology.

Natalya A. Plasteeva [plasteeva@rambler.ru] \& Pavel A. Kosintsev [kpa@ipae.uran.ru], Institute of plant and animal ecology, Russian Academy of Sciences, 8 Marts st., 202, Ekaterinburg, 620144, Russia; Sergey K. Vasiliev [svasiliev@archaeology.nsc.ru], Institute of archaeology and ethnography,Russian Academy of Sciences, Lavrent'eva prosp. 17, Novosibirsk, 630090, Russia; Novosibirsk State University, Pirogova Str.2, Novosibirsk, 630090, Russia.

\section{Equus (Sussemionus) ovodovi Eisenmann, Vasiliev, 2011 в позднем плейстоцене Западной Сибири}

\section{Н.А. Пластеева, С.К. Васильев, П.А. Косинцев}

РЕЗЮМЕ. Костные остатки мелкой формы лошади часто встречаются в позднеплейстоценовых отложениях юга Западной Сибири. Повторное изучение ископаемого материала, ранее относимого к E. hydruntinus или E. hemionus, показало их принадлежность к E. ovodovi. Морфологически этот вид характеризуется стройными метакарпальными и метатарзальными костями, коротким протоконом на верхних зубах, V-образной лингвальной долинкой и присутствием изолированных столбиков на нижних зубах. В позднем плейстоцене вид был широко представлен на юге Западной Сибири. Находки E. ovodovi происходят с территории Приобского плато, Алтая и Кузнецкого Алатау. На восток ареал доходил, по меньшей мере, до Енисея. Радиоуглеродные даты свидетельствуют о том, что E. ovodovi обитала на рассматриваемой территории вплоть до конца каргинского интерстадиала.

КЛЮЧЕВЫЕ СЛОВА. Equus ovodovi, Equidae, плейстоцен, Западная Сибирь, морфология.

\section{Introduction}

During the Late Pleistocene, southwestern Siberia was inhabited by two coexisting equids: the large-sized caballoid Equus ferus Boddaert, 1785 and a smallsized horse. Remains of small-sized horse have been attributed to Equus hemionus Pallas, 1775 (Galkina \& Ovodov, 1975; Foronova, 1990) or Equus hydruntinus Regalia, 1907 (Derevianko et al., 1990; Foronova, 1990; Derevianko et al., 2003; Vasiliev et al., 2006a; Vasiliev et al., 2006b). Fossil material obtained from several caves in the Altai Mountains (Vasiliev et al., 2008) and alluvial sites of the Pre-Altai Plain (Vasiliev \& Orlova, 2006) indicate that in the Late Pleistocene this small horse was broadly distributed in the area and commonly served as prey for animal predators and ancient humans.

Recent DNA study of horse remains from Proskuriakova Cave (Khakassia) revealed that it does not belong, as was previously thought, to E. hydruntinus or true horses but represents a separate monophyletic group of equids (Orlando et al., 2009). On the basis of skeletal remains from the cave a new species was described Equus ovodovi Eisenmann, Vasiliev, 2011 (Eisenmann \&Vasiliev, 2011). The name honors N.D. Ovodov who excavated faunal remains from Altai caves, including Proskuriakova Cave.

Radiocarbon age of E. ovodovi bones from Proskuriakova Cave corresponds to 42.4-45.7 kyr BP. Detailed examination of tooth and skeletal morphology of the new species showed that E. ovodovi belongs to the subgenus Sussemionus, supposedly extinct in the Middle Pleistocene (Eisenmann, 2010). These equids were widespread in the first half of the Pleistocene from Western Europe through eastern Siberia and Alaska (Eisenmann et al., 2008). The discovery of E. ovodovi in Khakassia suggests that sussemiones survived in western Siberia until the end of the Late Pleistocene. 
Table 1. List of localities and number of examined specimens (small equid / large equid).

\begin{tabular}{lcccc}
\hline \multicolumn{1}{c}{ Locality } & Lat; Long & Teeth & Mc III & Mt III \\
\hline Hyena's Den Cave & 51,$3 ; 83,1$ & $329 / 68$ & $11 / 14$ & $12 / 4$ \\
Okladnikova cave & 51,$4 ; 84,0$ & - & $3 / 3$ & $2 / 1$ \\
Taradanovo & 53,$5 ; 81,5$ & - & $4 / 76$ & $4 / 64$ \\
Chik & 54,$5 ; 82,5$ & - & $1 / 48$ & $-/ 35$ \\
Kurtak & $55 ; 91$ & - & $17 / 36$ & $14 / 27$ \\
Irtysh river & $57,4-58,4 ; 68-71$ & $12 / 50$ & 37 & - \\
Merimy & 58,$0 ; 68,0$ & $2 / 4$ & 28 & - \\
Abatskoe & 56,$2 ; 70,3$ & - & 6 & - \\
Blinnikovo & 57,$5 ; 68,0$ & - & 4 & - \\
Epanchino & 58,$1 ; 68,4$ & - & 4 & - \\
\hline
\end{tabular}

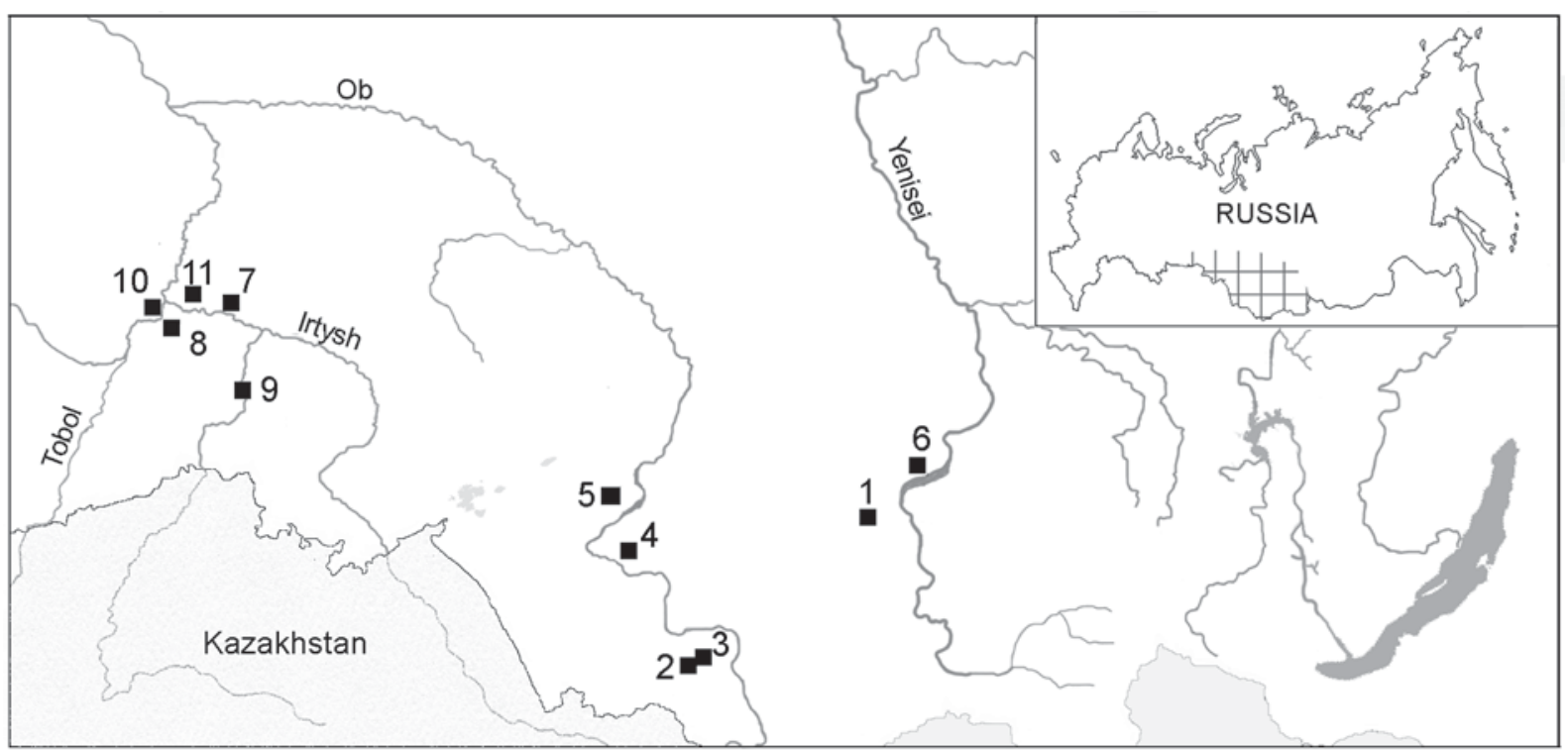

Fig.1. Map of the Pleistocene localities with equid remains.

1 - Proskuriakova Cave, 2 - Hyena's Den Cave, 3 - Okladnikova cave, 4 - Taradanovo, 5 - Chik, 6 - Kurtak, 7 - Irtysh, 8 Merimy, 9 - Abatskoe, 10 - Blinnikovo, 11 - Epanchino.

In this paper we present a description and re-examination of the small horse remains from several additional sites, located in the southern part of western Siberia.

\section{Materials and methods}

Small equid remains were found in alluvial sites in the Ob River basin (Chik, Taradanovo) and cave sites in Altai (Denisova, Kaminnaya, Strashnaya, Chagyrskaya, Hyena's Den, Okladnikova) in association with caballoid horses. These two groups of equids differ from each other in size and proportions of skeletal elements. Most of the bones, except small fragments, vertebrae, ribs and bones from juvenile specimens can be attributed to each size group visually. Horse remains from cave deposits accumulated by predators or ancient humans are highly fragmented so fossil material from Denisova, Kaminnaya, Strashnaya and Chagyrskaya caves (Vasiliev, 2009; Vasiliev \& Zenin 2009; Lobachev et al., 2012) is not presented in this paper.

The current study focuses on horse teeth, metacarpal and metatarsal bones from Hyena's Den and Okladnikova caves, Taradanovo and Chik alluvial sites (Tab. 1, Fig. 1). Small equid remains from these sites were initially identified as E. hydruntinus (Vasiliev, 2004; Vasiliev et al., 2006b). Only permanent teeth (P2-M3, p2-m3), metacarpal (mc III) and metatarsal (mt III) bones with fully fused epiphyses from adult individuals were included in the analysis.

In order to clarify the distribution of small equid in southwestern Siberia we used additional unpublished data on fossil horses from the rivers Irtysh (Epanchino, Irtysh), Ishym (Abatskoe), Tobol (Merimy, Blinnikovo) and Yenisei (Kurtak). All materials originated from alluvial sites and most of the bones can be dated to MIS 3 (Krivonogov, 1988; Vasiliev et al., 2008).

Data on E. ovodovi from Proskuriakova Cave are cited according to Eisenmann \& Vasiliev (2011). 
Table 2. Radiocarbon dates for bones of small equid remains from Western Siberia (noncalibrated values).

\begin{tabular}{lcccc}
\hline \multicolumn{1}{c}{ Locality } & Sample & Lab.No. & ${ }^{14}$ C BP & Source \\
\hline Proskuriakova Cave & E. ovodovi & CURL-10275 & $42480 \pm 1500$ & Orlando et al., 2009 \\
Proskuriakova Cave & E. ovodovi & CURL-10284 & $45770 \pm 2250$ & Orlando et al., 2009 \\
Chik & small equid & SPb-1343 & $23200 \pm 800$ & this paper \\
Taradanovo & small equid & SPb-1340 & $28340 \pm 800$ & this paper \\
\hline
\end{tabular}

The radiocarbon age of the cave deposits (Proskuriakova, Okladnikova, and Hyena's Den caves) and Chik alluvial site corresponds to the Karginian Interstadial, MIS 3 (Krause et al., 2007; Vasiliev et al., 2008; Orlando et al., 2009; Lobachev et al., 2012). Series of radiocarbon dates from Taradanovo, except several infinite dates, correspond to MIS 3 (Vasiliev \& Orlova, 2006) and most of the mammal remains belong to Late Pleistocene faunal complex (Vasiliev et al., 2008). Radiocarbon dates on E. ovodovi from Proskuriakova Cave and small horse remains from Chik and Taradanovo provide an age range between 45 and $23 \mathrm{kyr} \mathrm{BP}$ (Tab. 2).

For comparative purposes we used data on fossil caballoid horses, E. hemionus and E. hydruntinus. Holocene occurrence of $E$. hemionus in western Siberia has been reported (Ermolova, 1978; Devyashin \& Kosintsev, 2013), but there is no secure evidence of this species from Pleistocene deposits. The presence of $E$. hemionus in southwestern Siberia during the Late Pleistocene is still debatable, that is why for morphological comparison we used data on modern Mongolian wild ass (V. Eisenmann, online data). The sample of $E$. hydruntinus comes from several Crimean sites (Eisenmann \& Baryshnikov, 1994; Kuzmina, 1997; van Asperen et al., 2011).

Teeth were measured following Eisenmann et al. (1988) with author's designations. On each tooth occlusal length (L) and width (W), length of the protocone (LP) and postflexid (LPF) were measured. For each sample the protocone $(\mathrm{IP}=\mathrm{LP} \times 100 / \mathrm{L})$ and postflexid $(\mathrm{IF}=\mathrm{LPF} \times 100 / \mathrm{L})$ indexes were also calculated. Size and shape of horse teeth vary with stage of wear (Plasteeva, 2013) and their size variation is especially noticeable in highly worn and unworn specimens. In this work dental measurements were taken from samples with a crown height of $30-50 \mathrm{~mm}$. Absolute crown height was measured on the buccal side from the division of the roots to the occlusal surface. From metacarpal and metatarsal bone 12 dimensions proposed by Eisenmann \& Beckouche (1986) were taken. The slenderness index $(3 \times 100 / 1)$ and distal sagittal keel index $(14 \times 100 / 12)$ were used to compare absolute size and relative proportions of third metapodials. All measurements were taken with a digital caliper to the nearest $0.1 \mathrm{~mm}$.

Size and shape differences of dental elements, metacarpal and metatarsal bones were analyzed using log ratio diagrams, descriptive, nonparametric (Mann-Whitney $U$ test) and multivariate statistics (principal component analysis performed on raw data). Data were checked for normality by the Shapiro-Wilk test. The data from
Kurtak is not normally distributed (measurements 1, 4 and 5 on metacarpal bone), so differences in size between two groups of equids were analyzed using MannWhitney $U$ test. In order to analyze overall size differences in the equid sample from southwestern Siberia we used principal component analysis. All statistical analyses were performed using Statistica 5.0 (Statsoft Inc., www.statsoft.com).

Histogram and scatter plot are presented for metacarpal bone; results for the metatarsal bone are only discussed in the text.

All examined material is stored in the Institute of archaeology and ethnography (Novosibirsk) and Institute of plant and animal ecology (Ekaterinburg).

\section{Systematic paleontology}

Order Perissodactyla Owen, 1848

Family Equidae Linnaeus, 1758

Genus Equus Linnaeus, 1758

Subgenus Sussemionus Eisenmann, 2010

Equus (Sussemionus) ovodovi Eisenmann \& Vasiliev, 2011

Type locality. Proskuriakova Cave, Khakassia, Russia.

Material. Hyena's Den Cave: upper cheek teeth: P2 - 34, P3-4 - 52, M1-2 - 77, M3 - 37; lower cheek teeth: p2 - 21, p3-4 - 49, m1-2 - 41, m3 - 20; third metacarpal bone 11; third metatarsal bone -12 . Chik: third metacarpal bone 1. Okladnikova cave: third metacarpal bone -2 ; third metatarsal bone -2 . Taradanovo: third metacarpal bone -4 ; third metatarsal bone -4 (collections IAET RAS).

Description and comparison. Absolute sizes of the upper and lower cheek teeth are given in Appendix I, II. The size of the cheek teeth of small horse from Hyena's Den Cave is similar to E. ovodovi from Proskuriakova Cave and $E$. $h$. hemionus, but larger than size of the teeth of E. hydruntinus. The protocone is short on the premolars; on the molars it can be elongated (Fig. 2 ). The anterior half of the protocone is smaller than the posterior. The base of the protocone can be hollow or flat. The size of the pli caballine varies greatly. The enamel on the teeth is plicated, sometimes - highly plicated. E. hydruntinus and E. hemionus, on the other hand, characterized by the simple enamel pattern and short, reduced pli caballine (Eisenmann, 1980; van Asperen et al., 2011).

The double knot on the lower teeth is asymmetrical, with an elongated metaconid. The enamel pattern on 

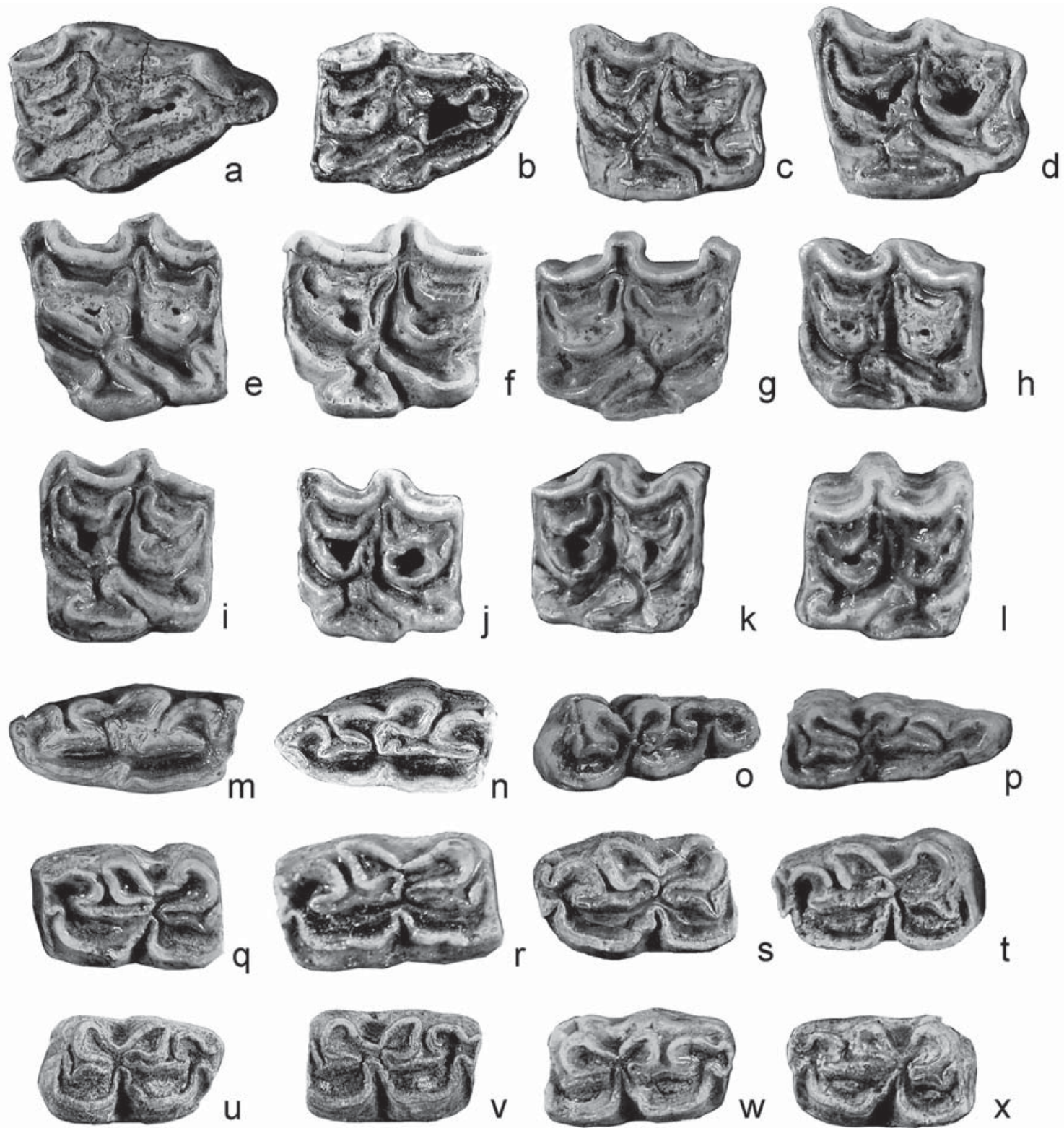

0

2

Fig. 2. Upper and lower cheek teeth of small equid from Hyena's Den Cave: a, b - P2 dex; c, d - M3 sin; e, f - P3-4 sin; g - P3-4 dex; h, i, j- M1-2 sin; k, 1-M1-2 dex; m, n - p2 sin; o, p-m3 sin; q, r, s, t-p3-4 dex; u, v, w - m1-2 $\sin ; \mathrm{x}-\mathrm{m} 1-2$ dex.

the lower dentition can include isolated stylids. The inner (lingual) valley is shallow. The ectoflexid is deep on the molars and sometimes penetrate the neck of the double knot as in E. hydruntinus. The ectoflexid on the lower teeth of extant Mongolian wild ass only reaches the neck of the double knot. Buccal wall of the protoand hypoconids on the molars can be flat or rounded and differs in that from E. hydruntinus (Davis, 1980). These morphological traits are similar to E. ovodovi from Proskuriakova Cave. Protocone indices of small equid teeth are greater than those of E. hydruntinus but can overlap in their values with extant E. h. hemionus; postflexid indices shows the opposite (Fig. 3).

The metacarpal and metatarsal bones are more slender than in E. ferus (Eisenmann, 1979), with a small developed sagittal crest on the distal end (Appendix III-IV). The posterio-external process on the proximal end of metatarsal bone is small (Fig. 4). Distal articular breadth is nearly equal or smaller than supra-articular breadth, in contrast to caballoid horses.

As compared to extant Mongolian wild ass and $E$. hydruntinus the metacarpals and metatarsals of $E$. 


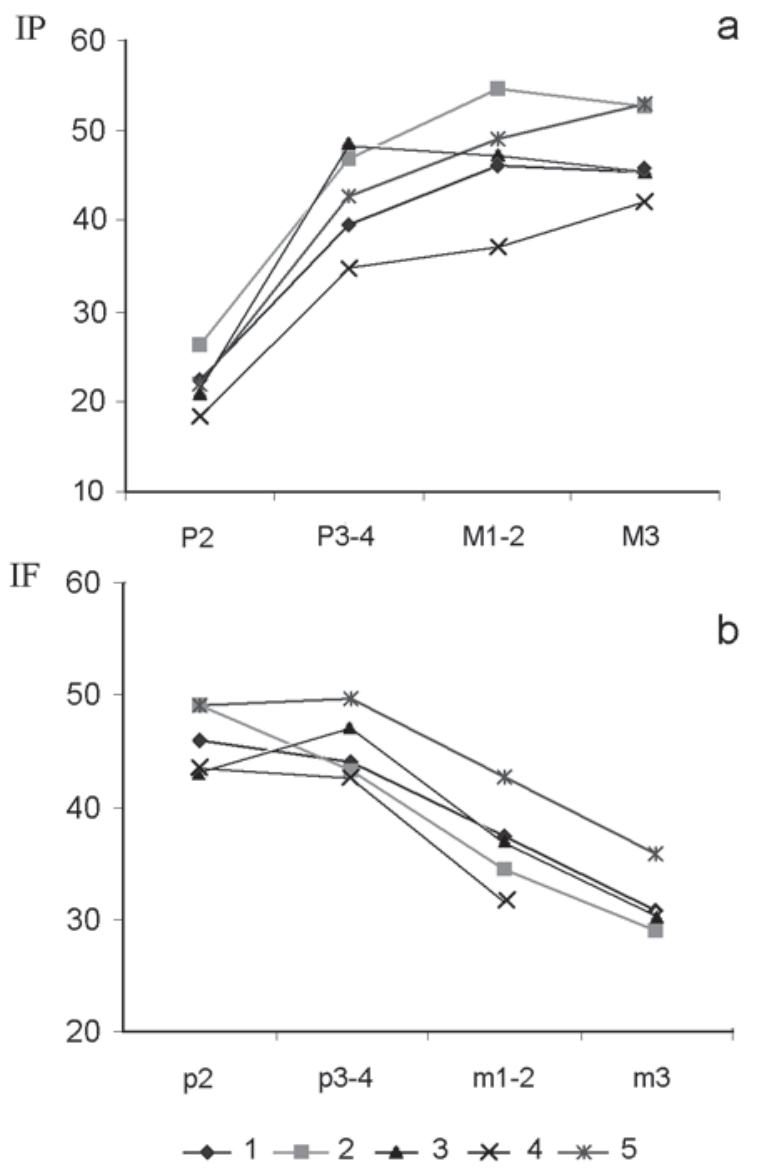

Fig. 3. Ratio diagrams of upper (a) and lower (b) dental proportions: 1 - small equid Hyena's Den Cave; $2-E$. ferus Hyena's Den Cave; $3-E$. ovodovi Proskuriakova Cave (Eisenmann \& Vasiliev, 2011); $4-$ E. hydruntinus Prolom 2 (Eisenmann \& Baryshnikov, 1994); $5-$ E. h. hemionus. ovodovi are larger and more robust with a deep diaphysis (Tab. 3).

Mean values and variation limits of relative breadth of the diaphysis in E. h. hemionus lower than in fossil horses from southwestern Siberia. Modern wild asses and E. hydruntinus are similar to E. ovodovi in small developed sagittal crest on the distal end on the third metapodials.

Morphological differences between three equid species reflect log ratio diagrams (Fig. 5). Log ratio diagrams of small equid metacarpals from Okladnikova cave, Taradanovo, and Hyena's Den Cave are similar to $E$. ovodovi from the type locality and distinguish from those of caballoid horses, E. hydruntinus and E. $h$. hemionus. For the metatarsal bone, log ratio diagrams follow the same pattern and show differences in absolute size and relative proportions between E. ovodovi, E. ferus, E. h. hemionus and E. hydruntinus.

Based on size and morphology of skeletal elements the small equid from Hyena's den and Okladnikova caves, Taradanovo and Chik determined as E. ovodovi.

\section{Results and discussion}

Distribution of $\boldsymbol{E}$. ovodovi in Western Siberia. To clarify the distribution of $E$. ovodovi in southwestern Siberia we examined multiple data on horse remains from different alluvial sites to the west and east from Altai and Khakassia. There are several alluvial sites from the Tobol, Irtysh, Ishym and Yenisei river valleys (Fig. 1) with large number of equid remains which dates to MIS III.

Morphological study of 68 dental specimens (13 upper and lower dental rows and six isolated teeth) showed no evidence of $E$. ovodovi in alluvial samples from Irtysh river. All specimens belong to E. ferus. The

Table 3. Relative proportions (n; Mean / Min-Max) of metacarpal and metatarsal bones of fossil equids from Proskuriakova Cave (Eisenmann \& Vasiliev, 2011), Hyena's Den Cave, Chik, Taradanovo, Kurtak and modern E. h. hemionus (V.

Eisenmann, online data).

\begin{tabular}{|c|c|c|c|c|}
\hline \multirow{2}{*}{ Species } & \multicolumn{2}{|c|}{ Metacarpal bone } & \multicolumn{2}{|c|}{ Metatarsal bone } \\
\hline & slenderness index & distal sagittal keel index & slenderness index & distal sagittal keel index \\
\hline \multirow{3}{*}{$\begin{array}{l}\text { E. ovodovi } \\
\text { E. ferus }\end{array}$} & \multicolumn{4}{|c|}{ Proskuriakova Cave } \\
\hline & \multirow{2}{*}{$\begin{array}{c}1 ; 13.3 \\
-\end{array}$} & \multirow{2}{*}{$\begin{array}{l}- \\
- \\
\end{array}$} & $6 ; 11.0 / 10.5-11.5$ & $4 ; 86.2 / 81.8-90.0$ \\
\hline & & & $3 ; 13.5 / 13.0-13.7$ & $3 ; 83.3 / 80.9-86.0$ \\
\hline \multirow{3}{*}{$\begin{array}{l}\text { small equid } \\
\text { E. ferus }\end{array}$} & \multicolumn{4}{|c|}{ Hyena's Den cave } \\
\hline & $10 ; 13.9 / 12.8-14.9$ & $11 ; 89.1 / 86.3-92.8$ & $7 ; 11.8 / 10.8-12.5$ & $11 ; 87.0$ / 84.9-90.6 \\
\hline & $5 ; 17.8 / 17.2-18.7$ & $11 ; 83.0 / 79.2-86.1$ & $4 ; 14.4 / 13.6-15.7$ & $3 ; 84.2 / 81.5-87.2$ \\
\hline \multirow{3}{*}{$\begin{array}{l}\text { small equid } \\
\text { E. ferus }\end{array}$} & \multicolumn{4}{|c|}{ Taradanovo } \\
\hline & $3 ; 14.0 / 13.6-14.4$ & $4 ; 88.3$ / 84.7-92.3 & $2 ; 11.2 ; 11.5$ & $5 ; 85.5 / 84.4-86.9$ \\
\hline & $62 ; 16.4 / 14.7-18.1$ & $72 ; 82.7 / 77.4-90.9$ & $63 ; 13.0 / 11.0-14.9$ & $64 ; 83.2 / 77.3-87.3$ \\
\hline \multirow[b]{2}{*}{ small equid } & \multicolumn{4}{|c|}{ Chik } \\
\hline & - & - & $1 ; 14.4$ & $1 ; 89.4$ \\
\hline \multirow{3}{*}{$\begin{array}{l}\text { small equid } \\
\text { E. ferus }\end{array}$} & \multicolumn{4}{|c|}{ Kurtak } \\
\hline & $15 ; 12.9 / 11.9-13.6$ & $17 ; 88.5$ / 83.3-92.4 & $14 ; 10.6 / 9.6-12.2$ & $12 ; 88.9 / 85.0-95.5$ \\
\hline & $36 ; 16.4 / 14.9-17.9$ & $34 ; 82.8 / 79.8-88.6$ & $27 ; 13.3 / 11.9-14.8$ & $27 ; 83.4$ / 79.6-86.9 \\
\hline E. h. hemionus & $10 ; 11.8 / 10.9-12.7$ & $10 ; 89.8 / 87.1-93.5$ & $10 ; 9.7 / 8.8-10.4$ & $10 ; 87.8$ / 84.5-90.3 \\
\hline
\end{tabular}



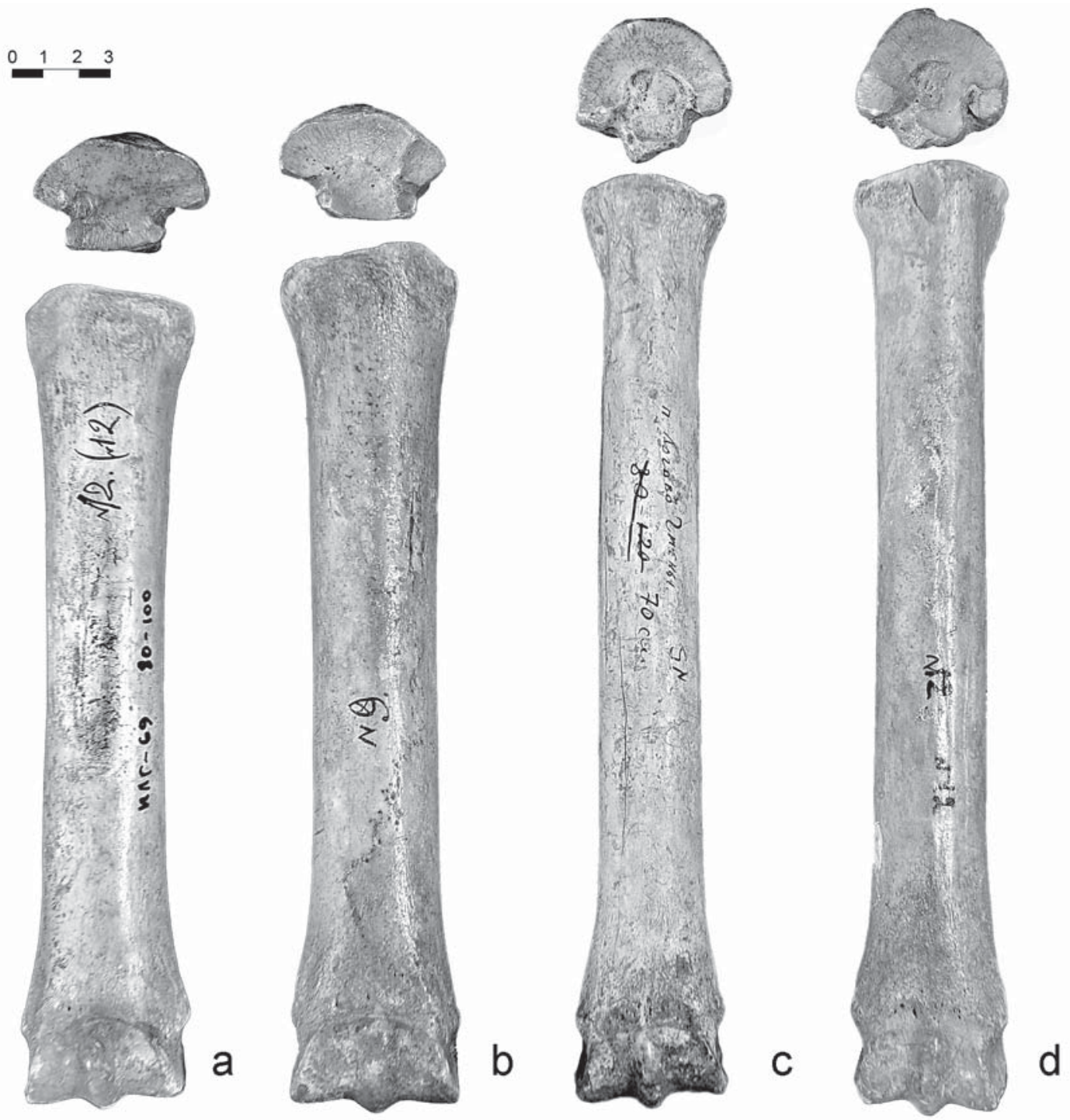

Fig. 4. Metacarpal $(a, b)$ and metatarsal $(c, d)$ bones of small equid from Hyena's Den Cave.

protocone on the upper teeth is elongated. The double knot on the lower teeth is asymmetrical, with U-shaped lingual valley. Isolated stylids are absent. Principal component analysis of complete metacarpal bones $(n=139)$ from southwestern Siberia indicates significant variation in shape but little variation in size. The first two principal components explain $85 \%$ of the total sample variance. First principal component (PC1) with negative factor loadings is strongly correlated with most of the original values (measurements 3-14) and PC2 reflects the length of the metacarpal bone (Appendix V).

A scatter plot of PC scores (Fig. 6) illustrates a clear separation between E. ferus and E. ovodovi material from Altai and Khakassia on PC1. This separation reflects a difference in metacarpal proportions: $E$. ovodovi has more slender, gracile bones than caballoid horses.

So we can assume that to the west of Priobskoye Plateau up to the Urals (Kuzmina, 2000) there is no evidence of small equid remains. PC analysis also revealed that the sample from Kurtak (eastern Sayan Mountains) falls into two groups and 17 specimens fall within the distribution of E. ovodovi from Altai and Khakassia. Mann-Whitney test on metacarpal $\left(\mathrm{N}_{\mathrm{sm}}\right.$ equid $\left.=17, \mathrm{~N}_{E \text {. ferus }}=36\right)$ and metatarsal $\left(\mathrm{N}_{\text {small equid }}=14, \mathrm{~N}_{E}\right.$ ${ }_{\text {ferus }}=27$ ) bones between the two groups of equids from Kurtak produce a significant result for original measurements (Appendix VI).

Small equid remains from Kurtak were previously attributed to E. hemionus (Ovodov, 1992; Kuzmin, 2011). The lack of horse teeth in the sample makes it difficult to determine the taxonomic position of the small equid from Kurtak. Based on skeletal morphology the small horse from Kurtak resembles E. ovodovi from Altai and Khakassia. Despite the difference in size, metacarpal and metatarsal proportions from Kurtak (Tab. 3) are similar to E. ovodovi. Differences in absolute size of the bones can reflect regional variabil- 


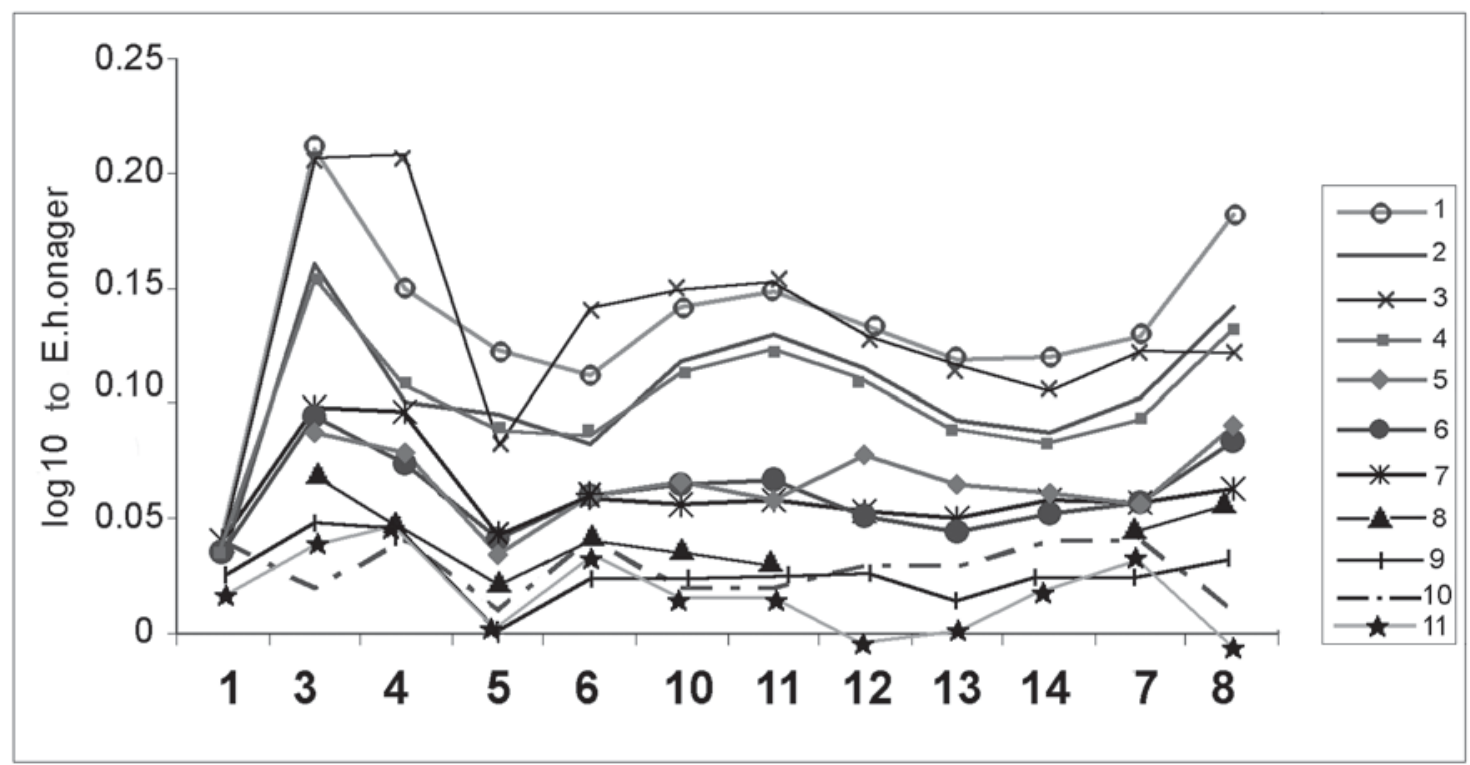

Fig. 5. Log ratio diagrams of measurements on equid metacarpals.

E. ferus: 1 - Okladnikova cave $(\mathrm{n}=3), 2$ - Taradanovo $(\mathrm{n}=76), 3$ - Hyena's Den Cave $(\mathrm{n}=14) ; 4$. Kurtak $(\mathrm{n}=36)$; small equid: 5 - Okladnikova cave $(\mathrm{n}=3), 6$ - Taradanovo $(\mathrm{n}=4), 7$ - Hyena's Den Cave $(\mathrm{n}=11), 8$ - E. ovodovi Proskuriakova Cave $(\mathrm{n}=4) ; 9-\operatorname{Kurtak}(\mathrm{n}=17) ; 10-E$. h. hemionus $(\mathrm{n}=10) ; 11-$ E. hydruntinus (van Asperen et al., 2011).

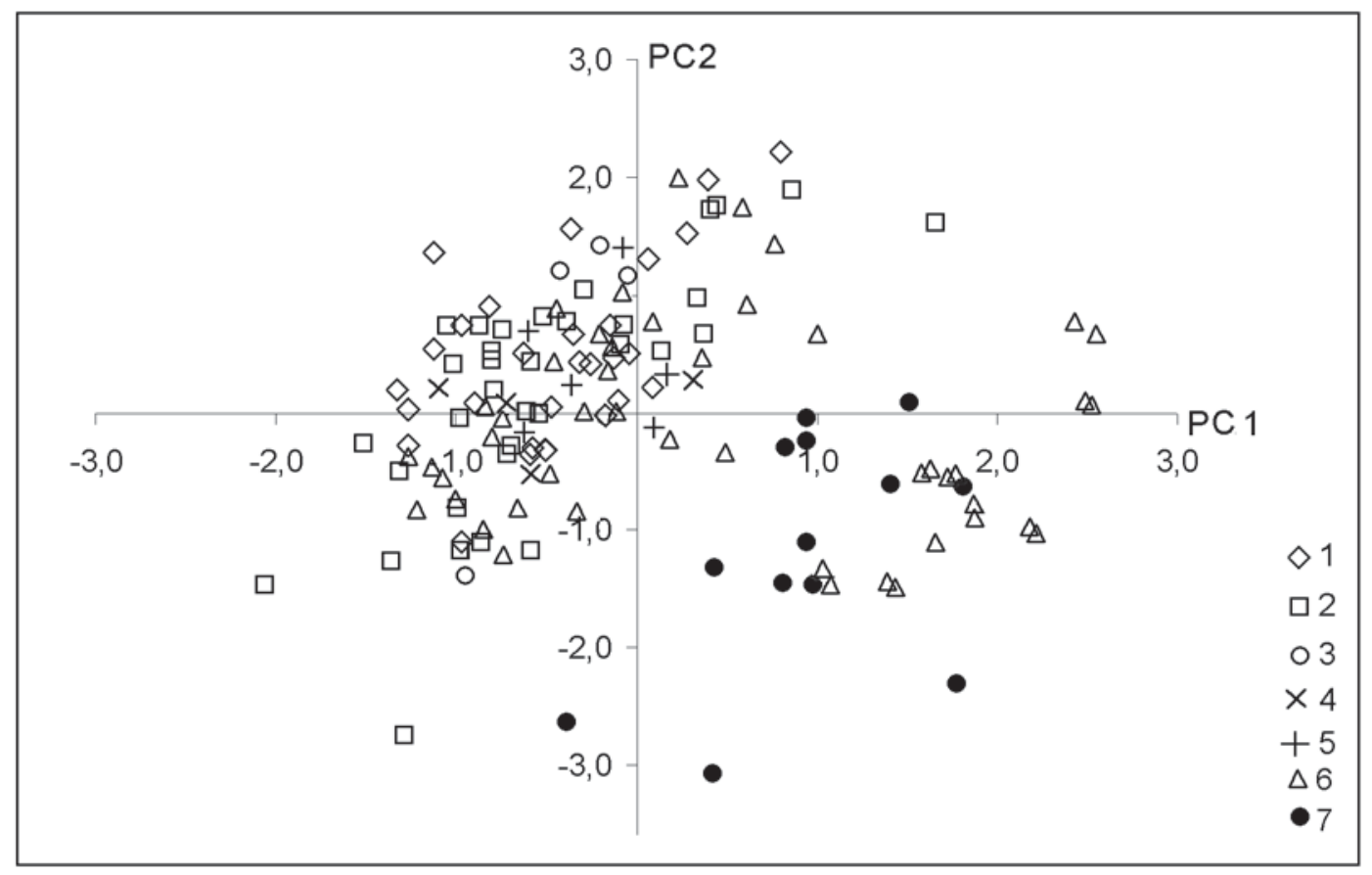

Fig. 6. Results of PC analysis of horse metacarpals.

1 - Merimy (n=28), 2 - Irtysh (n=37), 3 - Epanchino $(\mathrm{n}=4), 4-$ Blinnikovo $(\mathrm{n}=4), 5-$ Abatskoe $(\mathrm{n}=6), 6-\operatorname{Kurtak}(\mathrm{n}=47), 7-E$. ovodovi from Chik, Taradanovo, Hyena's Den Cave ( $\mathrm{n}=13)$.

ity of horses in the Late Pleistocene or chronological heterogeneity of fossil material.

The geographical distribution of E. ovodovi in the Late Pleistocene was probably restricted to Northern Asia. In Eastern Europe E. ovodovi is replaced by E. hydruntinus. In the Late Pleistocene it was widespread in the south of the Russian Plain, Crimea, and Caucasus
(Gromova, 1949; David, 1982). The presence of E. hydruntinus in Northern Asia during the Pleistocene is not confirmed (Orlando et al., 2006; Eisenmann et al., 2008).

The number of E. ovodovi remains considerably increases from the north southward. In Priobskoye Plateau (Chik and Taradanovo) the number of bones is low (0.1-1.6\% from large mammals fauna), in the cave 
deposits from Altai and Kuznetsk Alatau it increases to $0.2-3.2 \%$ and even reaches $33 \%$ in the Hyena's Den Cave. Though the northern limit of range is unclear, we can assume that $E$. ovodovi inhabited the south of Western Siberia and its range did not expand far to the north.

The eastern part of the range reached the Yenisei River and apparently extended further east. E. ovodovi was identified from the south cis-Baikalian region (Klementiev et al., 2011). Small and slender equid remains referred to E. hemionus (Ravskii et al., 1964; Konstantinov \& Nemerov, 1978; Kasparov, 1986; Klementiev, 2008; Vasiliev, 2003) are reported from the Pleistocene deposits up to the Transbaikalia. After the discovery of Sussemione horses these materials should be re-examined. Species identification of equid remains is rather difficult because of their marked size overlap. The size of the skeletal elements places $E$. ovodovi between $E$. ferus and hemione-like equids.

Recent study of mitochondrial DNA shows that $E$. ovodovi is more closely related to asses and zebras, than caballoid horses (Orlando et al., 2009; Vilstrup et al., 2013). It shares dental and postcranial characters such as shape of the protocone and the double knot, slender third metapodials with a small developed sagittal crest with both E. hydruntinus and E. hemionus. E. ovodovi also have some primitive features like highly plicated enamel and isolated stylids on their teeth; and primitive Equus characters like isolated stylids on the lower teeth. In the most part of their range Sussemiones went extinct at about 0,5 Ma (Eisenmann et al., 2008), while E. ovodovi inhabited southern Siberia till the end of the Kargin interstadial (MIS 3).

\section{Conclusions}

Two equid species, E. ovodovi and caballoid horse E. ferus, co-occured in Late Pleistocene of Western Siberia. The two species can be differentiated by dental morphology, size and proportions of skeletal elements. In the Late Pleistocene, E. ovodovi inhabited the southern part of Western Siberia. To the east its range reached at least the Yenisei River. Radiocarbon dates obtained from Proskuriakova, Chik, and Taradanovo sites suggest $E$. ovodovi survived in the area till the end of the Kargin interstadial (MIS 3).

ACKNOWLEDGEMENTS. The authors wish to thank N.D. Ovodov, Yu.V. Lobachev and L. Petrov for the opportunity to work with fossil material. We are sincerely grateful to Dr. Vadim Titov, Dr. Eline van Asperen, Dr. Alexey Klementiev, one anonymous reviewer and the Editor for their comments and suggestions which help us to improve the final version of the paper.

\section{References}

David A.I. 1982. [Development of mammal fauna of Moldavia in the Quaternary period]. Kishinev: Shtiinca. 151 p. [in Russian]
Davis S.J. 1980. Late Pleistocene and Holocene equid remains from Israel // Zoological Journal of the Linnean Society. Vol.70. P.289-312.

Derevianko A.P., Grichan Yu.V., Dergacheva M.I., Zenin A.N., Laukhin S.A., Levkovskaya G.M., Maloletko A.M., Markin S.V., Molodin V.I., Ovodov N.D., Petrin V.T.\& Shun'kov M.V. 1990. [Archaeology and paleoecology of the Paleolithic of the Altai Mountains]. Guidebook to International INQUA symposium "Chronostratigraphy of the Paleolithic of Northern, Central, Eastern Asia and America". Novosibirsk. P.127-133 [in Russian].

Derevianko A.P., Shun'kov M.V., Agadzhanayn A.K., Baryshnikov G.F., Malaeva E.M., Ul'yanov V.A., Kulik N.A., Postnov A.V. \& Anoikin A.A. 2003. [Environment and human in the Paleolithic of the Altai Mountains]. Novosibirsk: IAET SB RAS. P.214-219 [in Russian].

Devyashin M.M. \& Kosintsev P.A. 2013. [Ungulate mammals of Middle and Late Holocene of of the southeast of Western Siberia] // Vestnik Tomskogo universiteta. Biology. No.2(22). P.127-140 [in Russian, with English summary].

Eisenmann V. 1979. Les metapodes d'Equus sensu lato (Mammalia, Perissodactyla) // Geobios. Vol.12. P.863886 .

Eisenmann V. 1980. Les chevaux (Equus sensu lato) fossilizes et actuels: crânes et dents jugales superieures. Paris: Centre National de la Recherche scientifique. 186 p.

Eisenmann V. 2010. Sussemionus, a new subgenus of Equus (Perissodactyla, Mammalia) // Comptes rendus Biologies. Vol.333. P.235-240.

Eisenmann V., Alberdi M.T., de Giuli G. \& Staeche U. 1988. Studying fossil horses. Vol.1: Methodology // Collected papers after the "New York International Hipparion Conference, 1981”. Leiden; New York; København; Köln. $71 \mathrm{p}$.

Eisenmann V., Baryshnikov G. 1994. Equus cf. taubachensis et E. hydruntinus de la grotte de Prolom 2 (Crimee, Ukraine) // Bull. Mus. natl. Hist. Nat., Paris. Ser.4. T.16. Sect.C. No.2-4. P. 329-347.

Eisenmann V. \& Beckouche S. 1986. Identification and discrimination of metapodials from Pleistocene and modern Equus, wild and domestic // Meadow R.H. \& Uerpmann H.P. (eds.). Equids in the ancient world. Wiesbaden: Dr Ludwig Reichert Verlag. Vol.2. P.117-163.

Eisenmann V., Howe J. \& Pichardo M. 2008. Old World hemiones and New World slender species (Mammalia, Equidae) // Paleovertebrata. Vol.36. P.159-233.

Eisenmann V. \& Vasiliev S.K. 2011. Unexpected finding of a new Equus species (Perissodactyla, Mammalia) belonging to a supposedly extinct sub-genus in Late Pleistocene deposits of Khakassia (southwestern Siberia) // Geodiverisitas. Vol.33. No.3. P.519-530.

Equus actuels et récemment éteints // Vera Eisenmann: URL: http://www.vera-eisenmann.com/equidae-equus-actuelset-recemment-eteints-rubrique $17 . \mathrm{html}$

Ermolova N.M. 1978. [Theriofauna of Angara valley in the Late Quaternary period]. Novosibirsk: Nauka. 222 p. [in Russian]

Foronova I.V. 1990. [Fossil horses from Kuznetsk basin]. Novosibirsk: Institut geologii i geografii SO AN SSSR. 131 p. [in Russian] 
Galkina L.I. \& Ovodov N.D. 1975. [Quaternary mammal fauna from the Western Altai caves] // Systematics, fauna, zoogeography of mammals and their parasites. Novosibirsk: Nauka. P.165-180 [in Russian].

Gromova V. 1949. [Hystory of horses (genus Equus) in the Old world] // Trudy Zoologicheskogo instituta AN SSSR. Vol.7. No.1. 375 p. [in Russian]

Kasparov A.K. 1986. [Mammal remains from Late Paleolithic site Sukhotino 4 in the Transbaikalia] // Trudy Zoologicheskogo instituta AN SSSR. Vol.149. P.98-106 [in Russian].

Klementiev A.M. 2008. [Kulan (E. cf. hemionus) from the Late Pleistocene of Transbaikalia] // Fauna and flora of Northern Eurasia in the Late Cenozoic era. Ekaterinburg-Chelyabinsk: Rifey. P.186-198 [in Russian].

Klementiev A.M. Shchetnikov A.A., Sizov A.V. \& Filinov I.A. 2011. [Rare and problematic species of macroteriofauna in the Pleistocene fossil record of southern Baikal region] // Baikal zoological journal. Vol.8. No.3. P.5-9 [in Russian, with English summary].

Konstantinov M.V. \& Nemerov V.F. 1978. [Antiquities of the river Chikoy (northern boundaries of Mongolia)] // Okladnikov A.P. (ed.). Archeology and ethnography of Mongolia. Novosibirsk: Nauka. P.205-217 [in Russian].

Krause J., Orlando L., Serre D., Viola B., Prüfer K., Richards M.P., Hublin J.-J., Hänni C., Derevianko A.P. and Pääbo S. 2007. Neanderthals in central Asia and Siberia // Nature. Vol.449. doi:10.1038/nature06193.

Krivonogov S.K. 1988. [Stratigraphy and paleogeography of lower Irtysh valley in the last glaciation (on carpological data)]. Novosibirsk: Nauka. 232 p. [in Russian]

Kuzmina S.A. 2000. [Faunal data from the Late Paleolithic site Smelovskaya II in the South Urals] // Kosintsev P.A. (ed.). Pleistocene and Holocene Urals faunas. Chelyabinsk: Rifey. P.137-153 [in Russian, with English summary].

Kuzmin Ya. V. 2011. Mammalian fauna from Palaeolithic sites in the Upper Yenisei river basin (Southern Siberia): review of the current zooarchaeological evidence // International Journal of Osteoarchaeology. Vol.21. P.218-228.

Lobachev Yu.V., Vasiliev S.K. \& Orlova L.A. 2012. [Late Pleistocene theriofauna from Chumysh river (Altai Krai) and new data on Chik River site (Noviosibirsk oblast)] // Problems of archaeology, ethnography and anthropology of Siberia and adjacent territories. Vol.18. P.106-110 [in Russian].

Orlando L. Mashkour M., Burke A., Douady C.J., Eisenmann V. \& Hänni C. 2006. Geographic distribution of an extinct equid (Equus hydruntinus: Mammalia, Equidae) revealed by morphological and genetical analyses of fossils // Molecular Ecology. Vol.15. P.2083-2093.

Orlando L., Metcalf J.L, Alberdi M.T., Telles-Antunes M., Bonjean D., Otte M., Martin F., Eisenmann V., Mashkour M., Morello F., Prado J.L., Salas-Gismondi R., Shockey B.J., Wrinn P.J., Vasil'ev S.K., Ovodov N.D., Cherry M. I., Hopwood B., Male D., Austin J. J., Hänni C. \& Cooper A. 2009. Revising the recent evolutionary history of equids using ancient DNA // PNAS. Vol.106. No.51. P.21754-21759.

Ovodov N.D. 1992. [Quaternary theriofauna of the southern Pre-Yenisei Siberia] // Palaeoecology and settling of the ancient human in Northern Asia and America. Proceedings of the International Symposium. Krasnoyarsk. P.190 197 [in Russian].

Plasteeva N.A. 2013. [Late Pleistocene horses (Equus (Equus)) from Eastern Europe and the Urals]. Autoreferat. Ekaterinburg. P.11-12 [in Russian].

Ravskii E.I., Aleksandrova L.P., Vangengeim E.A., Gerbova V.G. \& Golubeva L.V. 1964. [Quaternary deposits from the south of Eastern Siberia] // Trudy Geologicheskogo instituta AN SSSR. No.105. 280 p. [in Russian]

Statsoft Inc. 1995. Statistica (data analysis software system), version 5.0. www.statsoft.com

van Asperen E.N., Stefaniak K., Proskurnyak I. \& Ridush B. 2012: Equids from Emine-Bair-Khosar Cave (Crimea, Ukraine): co-occurrence of the stenonid Equus hydruntinus and the caballoid E. ferus latipes based on skull and postcranial remains // Palaeontologia Electronica. Vol.15. No.1. 5A. 28 p.

Vasiliev S.A. 2003. Faunal exploitation, subsistence practices and Pleistocene extinctions in Paleolithic Siberia // Deinsea. Vol.9. P.513-556.

Vasiliev S.A. 2004. Taphonomic characteristics of Taradanovo secondary alluvial site // Problems of archaeology, ethnography and anthropology of Siberia and adjacent territories. Vol.10. P.164-168 [in Russian].

Vasiliev S.A. 2009. Animal remains from Chagyrskaya cave (north-west Altai) from the 2007 and 2008 years excavations // Problems of archaeology, ethnography and anthropology of Siberia and adjacent territories. Vol.15. P.50-55 [in Russian].

Vasiliev S.K. \& Orlova L.A. 2006. [A question about the age of Taradanovo site of large mammal fauna] // Problems of archaeology, ethnography and anthropology of Siberia and adjacent territories. Vol.12. P.29-32 [in Russian].

Vasiliev S.K., Derevianko A.P. \& Markin S.V. 2006a. [Large mammal fauna from northwestern Altai in the end of Sartan glacial (on material from Kaminnaya cave)] // Archaeology, ethnography and anthropology of Eurasia. Vol.2. No.26. P.2-22 [in Russian].

Vasiliev S.K., Ovodov N.D. \& Martynovich N.V. 2006b. [New paleoteriological investigation of Hyena cave (northwestern Altai)] // Problems of archaeology, ethnography and anthropology of Siberia and adjacent territories. Vol.12. P.43-49 [in Russian].

Vasiliev S.K. \& Zenin A.N. 2009. [Faunal remains from Strashnaya cave (northwestern Altai)] // Problems of archaeology, ethnography and anthropology of Siberia and adjacent territories. Vol.15. P.56-62 [in Russian].

Vasiliev S.K., Zenin A.N., Serdyuk N.V. \& Ul'yanov V.A. 2008. [New data on Hyena cave (northwestern Altai)] // Problems of archaeology, ethnography and anthropology of Siberia and adjacent territories. Vol.14. P.21-31 [in Russian].

Vilstrup J.T., Seguin-Orlando A., Stiller M., Ginolhac A., Raghavan M., Nielsen S. C. A., Weinstock J., Froese D., Vasiliev S.K., Ovodov N.D., Clary J., Helgen K.M., Fleischer R.C., Cooper A., Shapiro B. \& Orlando L. 2013. Mitochondrial phylogenomics of modern and ancient Equids // PLoS ONE. Vol.8. No.2. doi: 10.1371/ journal.pone.0055950. 
Appendix I. Measurements of the upper cheek teeth of equid specimens from Hyena's Den Cave ( $\mathrm{n}$; Mean \pm st. dev. / Min-Max) and comparative material (n; Mean / Min-Max), mm.

\begin{tabular}{|c|c|c|c|c|}
\hline Species & $\mathrm{P} 2$ & P3-4 & M1-2 & M3 \\
\hline \multicolumn{5}{|c|}{ Length } \\
\hline small equid, Hyena's Den Cave & $\frac{26 ; 36.0 \pm 2.06}{32.5-40.8}$ & $\frac{51 ; 27.2 \pm 1.08}{25.0-29.6}$ & $\frac{75 ; 24.2 \pm 1.20}{21.5-26.5}$ & $\frac{37 ; 27.9 \pm 1.57}{24.8-32.0}$ \\
\hline E. ferus, Hyena's Den Cave & $1 ; 40.0$ & $\frac{18 ; 28.8 \pm 1.77}{26.2-32.1}$ & $\frac{8 ; 27.7 \pm 0.9}{27.0-29.5}$ & $\frac{12 ; 30.8 \pm 1.94}{28.3-34.7}$ \\
\hline $\begin{array}{l}\text { E. ovodovi, Proskuriakova Cave } \\
\text { (Eisenmann \& Vasiliev, 2011) }\end{array}$ & $2 ; 32.0-35.5$ & $\frac{7 ; 26.3}{24.4-26.8}$ & $\frac{7 ; 24.1}{22.0-26.1}$ & $1 ; 28.2$ \\
\hline $\begin{array}{l}\text { E. hydruntinus, Prolom } 2 \text { (Eisenmann \& } \\
\text { Baryshnikov, 1994) }\end{array}$ & $\frac{8 ; 30.5}{27.3-32.8}$ & $\frac{13 ; 24.4}{22.3-26.2}$ & $\frac{26 ; 21.1}{19.0-23.6}$ & $\frac{13 ; 22.1}{19.5-24.5}$ \\
\hline E. hydruntinus, Crimea (Kuzmina, 1997) & $\frac{11 ; 31.4}{29.3-32.5}$ & $21 \frac{38 ;-}{6-27.3}$ & $\frac{55 ;-}{19.5-27.5}$ & $\frac{30 ; 22.6}{19.5-25.5}$ \\
\hline $\begin{array}{l}\text { E. hydruntinus, Emine-Bair-Khosar (van } \\
\text { Asperen et al., 2011) }\end{array}$ & $\frac{8 ; 32.5}{31.8-33.7}$ & $\frac{17 ; 25.2}{23.5-27.4}$ & $\frac{17 ; 22.3}{20.9-24.0}$ & $\frac{10 ; 24.3}{20.1-27.3}$ \\
\hline $\begin{array}{l}\text { E. h. hemionus (V. Eisenmann, online } \\
\text { data) }\end{array}$ & $\frac{16 ; 36.6}{33.0-39.0}$ & $\frac{36 ; 27.0}{23.5-29.0}$ & $\frac{36 ; 23.8}{21.5-27.0}$ & $\frac{16 ; 25.1}{20.0-30.0}$ \\
\hline \multicolumn{5}{|c|}{ Width } \\
\hline small equid, Hyena's Den Cave & $\frac{33 ; 24.7 \pm 1.34}{20.4-27.7}$ & $\frac{47 ; 26.8 \pm 1.32}{24.0-29.5}$ & $\frac{74 ; 26.3 \pm 1.24}{23.8-29.7}$ & $\frac{35 ; 23.6 \pm 1.0}{21.7-25.9}$ \\
\hline E. ferus, Hyena's Den Cave & $1 ; 27.8$ & $\frac{17 ; 29.7 \pm 1.71}{27.0-32.5}$ & $\frac{7 ; 29.6 \pm 1.4}{27.3-31.2}$ & $\frac{10 ; 25.5 \pm 1.76}{23.4-28.8}$ \\
\hline $\begin{array}{l}\text { E. ovodovi, Proskuriakova Cave } \\
\text { (Eisenmann \& Vasiliev, 2011) }\end{array}$ & $2 ; 20.7-24.7$ & $\frac{7 ; 26.6}{24.8-28.3}$ & $\frac{7 ; 26.2}{23.2-28.7}$ & $1 ; 23.0$ \\
\hline $\begin{array}{l}\text { E. hydruntinus, Prolom } 2 \text { (Eisenmann \& } \\
\text { Baryshnikov, 1994) }\end{array}$ & $\frac{7 ; 20.6}{17.2-22.5}$ & $\frac{13 ; 23.7}{21.9-25.9}$ & $\frac{26 ; 21.3}{19.2-22.9}$ & $\frac{13 ; 19.0}{16.4-21.4}$ \\
\hline E. hydruntinus, Crimea (Kuzmina, 1997) & $\frac{11 ; 21.3}{19.8-22.5}$ & $21.2-25.0$ & $20.0-25.0$ & $\frac{30 ; 19.2}{16.0-21.2}$ \\
\hline $\begin{array}{l}\text { E. hydruntinus, Emine-Bair-Khosar (van } \\
\text { Asperen et al., 2011) }\end{array}$ & $\frac{8 ; 21.8}{20.1-24.5}$ & $\frac{17 ; 24.2}{21.9-25.6}$ & $\frac{17 ; 23.3}{21.7-24.9}$ & $\frac{10 ; 20.9}{19.6-23.1}$ \\
\hline $\begin{array}{l}\text { E.h. hemionus (V. Eisenmann, online } \\
\text { data) }\end{array}$ & $\frac{16 ; 24.3}{22.5-27.5}$ & $\frac{36 ; 26.4}{25.0-28.0}$ & $\frac{36 ; 24.4}{22.5-26.5}$ & $\frac{16 ; 20.4}{17.2-24.0}$ \\
\hline \multicolumn{5}{|c|}{ Length of the protocone } \\
\hline small equid, Hyena's Den Cave & $\frac{34 ; 8.0 \pm 1.11}{6.2-9.8}$ & $\frac{50 ; 10.8 \pm 0.99}{8.5-13.3}$ & $\frac{76 ; 11.1 \pm 1.07}{8.5-13.3}$ & $\frac{37 ; 12.7 \pm 1.16}{10.4-15.0}$ \\
\hline E. ferus, Hyena's Den Cave & $1 ; 10.5$ & $\frac{18 ; 13.1 \pm 2.13}{10.0-16.3}$ & $\frac{9 ; 14.9 \pm 1.5}{13.2-17.0}$ & $\frac{12 ; 16.2 \pm 1.09}{15.0-18.0}$ \\
\hline $\begin{array}{l}\text { E.ovodovi, Proskuriakova Cave } \\
\text { (Eisenmann \& Vasiliev, 2011) }\end{array}$ & $2 ; 7.0-7.4$ & $\frac{7 ; 12.8 \pm 1.63}{10.2-14.1}$ & $\frac{7 ; 11.4 \pm 1.05}{10.3-13.3}$ & $1 ; 12.8$ \\
\hline $\begin{array}{l}\text { E. hydruntinus, Prolom } 2 \text { (Eisenmann \& } \\
\text { Baryshnikov, 1994) }\end{array}$ & $\frac{8 ; 5.6}{4.7-7.0}$ & $\frac{13 ; 8.5}{6.0-10.0}$ & $\frac{26 ; 7.8}{5.8-11.3}$ & $\frac{13 ; 9.3}{8.0-11.1}$ \\
\hline E. hydruntinus, Crimea (Kuzmina, 1997) & $\frac{10 ; 6.5}{5.5-7.5}$ & $\frac{38 ;-}{7.5-11.2}$ & $\frac{55 ;-}{6.0-11.5}$ & $\frac{30 ; 10.2}{8.0-12.0}$ \\
\hline $\begin{array}{l}\text { E. hydruntinus, Emine-Bair-Khosar (van } \\
\text { Asperen et al., 2011) }\end{array}$ & - & $\frac{17 ; 8.4}{7.0-10.2}$ & $\frac{17 ; 8.6}{7.4-9.9}$ & - \\
\hline $\begin{array}{l}\text { E.h. hemionus (V. Eisenmann, online } \\
\text { data) }\end{array}$ & $\frac{16 ; 8.0}{6.0-9.0}$ & $\frac{36 ; 11.6}{9.0-14.0}$ & $\frac{36 ; 11.7}{10.0-14.5}$ & $\frac{16 ; 13.2}{11.0-15.5}$ \\
\hline
\end{tabular}


Appendix II. Measurements of the lower cheek teeth of equid specimens from Hyena's Den Cave (n; Mean \pm st. dev. / Min-Max) and comparative material ( $\mathrm{n}$; Mean / Min-Max), mm

\begin{tabular}{|c|c|c|c|c|}
\hline Species & $\mathrm{p} 2$ & p3-4 & $\mathrm{m} 1-2$ & $\mathrm{~m} 3$ \\
\hline \multicolumn{5}{|c|}{ Length } \\
\hline small equid, Hyena's Den Cave & $\frac{19 ; 32.5 \pm 1.64}{30.0-36.2}$ & $\frac{48 ; 26.4 \pm 1.22}{23.3-29.1}$ & $\frac{41 ; 25.1 \pm 1.43}{23.0-28.7}$ & $\frac{20 ; 31.5 \pm 1.23}{29.0-32.9}$ \\
\hline E. ferus, Hyena's Den Cave & $\frac{3 ; 33.7 \pm 0.35}{33.5-34.1}$ & $\frac{11 ; 28.6 \pm 1.81}{25.9-31.8}$ & $\frac{6 ; 26.6 \pm 1.32}{24.8-28.4}$ & $\frac{7 ; 36.1 \pm 1.18}{35.0-37.9}$ \\
\hline $\begin{array}{l}\text { E.ovodovi, Proskuriakova Cave } \\
\text { (Eisenmann \& Vasiliev, 2011) }\end{array}$ & $\frac{5 ; 31.6}{28.8-34.5}$ & $\frac{12 ; 26.2}{24.0-28.4}$ & $\frac{12 ; 24.0}{21.4-24.7}$ & $\frac{6 ; 30.3}{28.2-31.7}$ \\
\hline $\begin{array}{l}\text { E. hydruntinus, Prolom } 2 \text { (Eisenmann } \\
\text { \& Baryshnikov, 1994) }\end{array}$ & $\frac{19 ; 26.6}{22.1-28.8}$ & $\frac{22 ; 23.4}{20.9-25.7}$ & $\frac{21 ; 21.6}{18.3-24.0}$ & $\frac{10 ; 25.8}{22.0-28.2}$ \\
\hline $\begin{array}{l}\text { E. hydruntinus, Crimea (Kuzmina, } \\
\text { 1997) }\end{array}$ & $\frac{25 ; 27.2}{25.0-30.0}$ & $\frac{55 ;-}{21.6-25.6}$ & $18.6-29.5$ & $\frac{20 ; 25.4}{22.0-27.5}$ \\
\hline $\begin{array}{l}\text { E. hydruntinus, Emine-Bair-Khosar } \\
\text { (van Asperen et al., 2011) }\end{array}$ & $\frac{5 ; 27.4}{24.5-28.7}$ & $\frac{12 ; 24.5}{21.1-26.1}$ & $\frac{11 ; 22.6}{20.9-24.0}$ & $\frac{9 ; 25.9}{20.9-28.6}$ \\
\hline $\begin{array}{l}\text { E.h. hemionus (V. Eisenmann, online } \\
\text { data) }\end{array}$ & $\frac{17 ; 31.2}{28.0-33.0}$ & $\frac{34 ; 27.5}{25.0-30.0}$ & $\frac{34 ; 24.7}{22.5-28.0}$ & $\frac{15 ; 29.2}{27.0-31.5}$ \\
\hline \multicolumn{5}{|c|}{ Width } \\
\hline small equid, Hyena's Den Cave & $\frac{21 ; 15.8 \pm 0.90}{13.6-17.4}$ & $\frac{47 ; 17.2 \pm 0.99}{14.7-19.0}$ & $\frac{37 ; 15.1 \pm 1.39}{12.0-18.0}$ & $\frac{19 ; 12.9 \pm 1.10}{11.4-14.8}$ \\
\hline E. ferus, Hyena's Den Cave & $\frac{3 ; 18.5 \pm 0.50}{18.0-19.0}$ & $\frac{11 ; 20.3 \pm 0.91}{19.0-22.0}$ & $\begin{array}{c}6 ; 18.9 \pm 0.46 \\
18.3-19.4\end{array}$ & $\frac{7 ; 16.6 \pm 0.74}{15.7-17.5}$ \\
\hline $\begin{array}{l}\text { E.ovodovi, Proskuriakova Cave } \\
\text { (Eisenmann \& Vasiliev, 2011) }\end{array}$ & $\frac{5 ; 15.7}{13.6-17.0}$ & $\frac{12 ; 17.4}{16.1-18.4}$ & $\frac{12 ; 16.4}{14.0-18.3}$ & $\underline{6 ; 13.5}$ \\
\hline $\begin{array}{l}\text { E. hydruntinus, Prolom } 2 \text { (Eisenmann } \\
\text { \& Baryshnikov, 1994) }\end{array}$ & $\frac{19 ; 12.5}{9.7-14.2}$ & $\frac{22 ; 13.8}{12.0-15.7}$ & $\frac{21 ; 12.3}{10.7-13.6}$ & $\frac{10 ; 11.1}{8.5-13.0}$ \\
\hline $\begin{array}{l}\text { E. hydruntinus, Crimea (Kuzmina, } \\
\text { 1997) }\end{array}$ & $\frac{25 ; 15.3}{13.5-18.0}$ & $\frac{55 ;-}{14.2-18.2}$ & $12.5-16.8$ & $-*$ \\
\hline $\begin{array}{l}\text { E. hydruntinus, Emine-Bair-Khosar } \\
\text { (van Asperen et al., 2011) }\end{array}$ & $\frac{5 ; 14.2}{13.2-15.6}$ & $\frac{12 ; 14.9}{13.2-17.2}$ & $\frac{11 ; 13.6}{12.2-16.0}$ & $\frac{9 ; 12.5}{10.8-13.5}$ \\
\hline $\begin{array}{l}\text { E.h. hemionus (V. Eisenmann, online } \\
\text { data) }\end{array}$ & $\frac{16 ; 14.6}{13.0-16.0}$ & $\frac{34 ; 16.1}{15.0-17.7}$ & $\frac{34 ; 14.3}{12.0-16.0}$ & $\frac{15 ; 12.6}{11.0-14.0}$ \\
\hline \multicolumn{5}{|c|}{ Length of the postflexide } \\
\hline small equid, Hyena's Den Cave & $\frac{21 ; 15.0 \pm 1.15}{13.0-17.0}$ & $\frac{49 ; 11.7 \pm 1.42}{8.0-14.0}$ & $\frac{39 ; 9.4 \pm 1.19}{6.5-12.3}$ & $\frac{20 ; 9.7 \pm 1.52}{7.2-13.4}$ \\
\hline E. ferus, Hyena's Den Cave & $\frac{3 ; 16.5 \pm 0.87}{15.5-17.0}$ & $\frac{11 ; 12.4 \pm 1.84}{9.2-15.0}$ & $\frac{6 ; 9.1 \pm 1.1}{8.2-11.0}$ & $\frac{7 ; 10.5 \pm 0.96}{9.3-12.1}$ \\
\hline $\begin{array}{l}\text { E.ovodovi, Proskuriakova Cave } \\
\text { (Eisenmann \& Vasiliev, 2011) }\end{array}$ & $\frac{5 ; 13.8}{8.8-16.2}$ & $\underline{12 ; 12.4}$ & $\frac{12 ; 8.8}{6.4-11.5}$ & $7.3-12.0$ \\
\hline $\begin{array}{l}\text { E. hydruntinus, Prolom } 2 \text { (Eisenmann } \\
\text { \& Baryshnikov, 1994) }\end{array}$ & $\frac{19 ; 11.6}{6.8-14.7}$ & $\frac{22 ; 10.0}{6.9-13.5}$ & $\frac{21 ; 6.8}{5.2-9.2}$ & - \\
\hline $\begin{array}{l}\text { E. hydruntinus, Crimea (Kuzmina, } \\
\text { 1997) }\end{array}$ & $\frac{25 ; 12.8}{10.5-15.5}$ & $8 . \frac{55 ;-}{2-14.0}$ & $5.04 ;-11.0$ & $\underline{20 ; 6.8}$ \\
\hline $\begin{array}{l}\text { E. hydruntinus, Emine-Bair-Khosar } \\
\text { (van Asperen et al., 2011) }\end{array}$ & $\underline{5 ; 12.4}$ & $\frac{12 ; 12.4}{10.7-15.5}$ & $\frac{11 ; 9.4}{6.4-12.1}$ & $\frac{9 ; 10.6}{8.3-11.7}$ \\
\hline $\begin{array}{l}\text { E. h. hemionus (V. Eisenmann, online } \\
\text { data) }\end{array}$ & $\frac{17 ; 15.3}{11.8-17.0}$ & $\frac{34 ; 13.7}{11.5-16.9}$ & $\frac{34 ; 10.5}{8.5-13.0}$ & $\begin{array}{c}7 ; 10.3 \\
9.0-11.0\end{array}$ \\
\hline
\end{tabular}

* In the original paper presented incorrect values 
Appendix III. Measurements $(\mathrm{mm})$ of third metacarpal bones of small equid from western Siberia (n; Mean \pm st. dev. / Min-Max) and comparative material on E. hydruntinus from Crimea and E. h. hemionus (n; Mean / Min-Max or n; Mean)

\begin{tabular}{|c|c|c|c|c|c|c|c|}
\hline \multirow[b]{2}{*}{ Measurement } & \multicolumn{4}{|c|}{ Small equid } & \multicolumn{2}{|c|}{ E. hydruntinus } & \multirow[b]{2}{*}{$\begin{array}{l}\text { E. h. hemi- } \\
\text { onus } \\
\text { (V. Eisen- } \\
\text { mann, } \\
\text { online data) }\end{array}$} \\
\hline & $\begin{array}{c}\text { Hyena's Den } \\
\text { Cave }\end{array}$ & $\begin{array}{l}\text { Okladni- } \\
\text { kova cave }\end{array}$ & Chik & Taradanovo & $\begin{array}{l}\text { Crimea } \\
\text { (Kuzmina, } \\
\text { 1997) }\end{array}$ & $\begin{array}{l}\text { Emine- } \\
\text { Bair- } \\
\text { Khosar } \\
\text { (van } \\
\text { Asperen et } \\
\text { al., 2011) } \\
\end{array}$ & \\
\hline 1. Maximal length & $\frac{11 ; 232.8 \pm 9.80}{219.0-250.3}$ & - & $1 ; 221.6$ & $\frac{3 ; 230.3 \pm 6.41}{225.3-237.5}$ & $\frac{33 ; 211.8}{196.0-228.0}$ & $5 ; 221.9$ & $\frac{10 ; 229.9}{220.0-240.0}$ \\
\hline $\begin{array}{l}\text { 3. Minimal breadth } \\
\text { of the diaphysis }\end{array}$ & $\frac{10 ; 32.5 \pm 2.12}{28.8-36.0}$ & $1 ; 31.7$ & $1 ; 31.8$ & $\frac{3 ; 32.2 \pm 0.40}{31.7-32.4}$ & $\frac{32 ; 26.1}{22.2-27.8}$ & $5 ; 28.8$ & $\frac{10 ; 27.1}{24.2-29.0}$ \\
\hline $\begin{array}{l}\text { 4. Depth of the } \\
\text { diaphysis }\end{array}$ & $\frac{10 ; 26.3 \pm 1.25}{24.9-28.2}$ & $1 ; 25.3$ & $1 ; 23.2$ & $\frac{3 ; 25.0 \pm 0.42}{24.7-25.5}$ & $\frac{34 ; 21.7}{18.2-23.5}$ & $5 ; 23.5$ & $\frac{9 ; 23.2}{22.0-25.0}$ \\
\hline $\begin{array}{l}\text { 5. Proximal } \\
\text { articular breadth }\end{array}$ & $\frac{11 ; 47.2 \pm 2.46}{43.6-51.7}$ & $\begin{array}{c}2 ; 45.2 \\
48.3\end{array}$ & $1 ; 44.9$ & $\frac{3 ; 47.5 \pm 0.46}{47.2-48.0}$ & $\frac{50 ; 41.0}{36.5-43.8}$ & $5 ; 43.2$ & $\frac{10 ; 44.4}{42.5-46.0}$ \\
\hline $\begin{array}{l}\text { 6. Proximal } \\
\text { articular depth }\end{array}$ & $\frac{10 ; 31.1 \pm 1.66}{28.5-33.5}$ & $\begin{array}{c}2 ; 30.2 \\
32.0\end{array}$ & $1 ; 29.9$ & $\frac{3 ; 31.1 \pm 0.10}{31.0-31.2}$ & $\frac{53 ; 29.3}{26.0-32.0}$ & $5 ; 29.4$ & $\frac{10 ; 29.7}{28.6-31.0}$ \\
\hline $\begin{array}{l}\text { 7. Maximal } \\
\text { diameter of the } \\
\text { articular facet for } \\
\text { the third carpal } \\
\text { bone }\end{array}$ & $\frac{11 ; 39.0 \pm 2.16}{36.0-42.9}$ & $\begin{array}{c}2 ; 38.0 \\
39.8\end{array}$ & $1 ; 37.4$ & $\frac{3 ; 39.0 \pm 0.53}{38.4-39.4}$ & - & $5 ; 36.7$ & $\frac{10 ; 37.2}{36.0-39.0}$ \\
\hline $\begin{array}{l}\text { 8. Diameter of the } \\
\text { articular facet for } \\
\text { the second carpal } \\
\text { bone }\end{array}$ & $\frac{11 ; 14.2 \pm 0.92}{39.3-47.9}$ & $\begin{array}{l}2 ; 14.8 \\
15.5\end{array}$ & $1 ; 12.5$ & $\frac{3 ; 14.9 \pm 0.85}{14.0-15.7}$ & - & $5 ; 12.0$ & $\frac{10 ; 12.7}{11.0-14.0}$ \\
\hline $\begin{array}{l}\text { 10.Distal maximal } \\
\text { supra-articular } \\
\text { breadth }\end{array}$ & $\frac{11 ; 44.1 \pm 2.46}{39.3-47.9}$ & $1 ; 45.0$ & $1 ; 44.1$ & $\frac{4 ; 44.9 \pm 0.65}{44.1-45.6}$ & - & $5 ; 40.1$ & $\frac{10 ; 40.3}{37.7-42.0}$ \\
\hline $\begin{array}{l}11 \text {. Distal maximal } \\
\text { articular breadth }\end{array}$ & $\frac{11 ; 44.0 \pm 2.13}{30.2-36.6}$ & $1 ; 44.0$ & $1 ; 43.2$ & $\frac{4 ; 44.9 \pm 1.29}{43.3-46.4}$ & $\frac{46 ; 36.9}{32.6-39.5}$ & $5 ; 40.0$ & $\frac{10 ; 40.7}{38.0-44.0}$ \\
\hline $\begin{array}{l}\text { 12. Distal maximal } \\
\text { depth of the keel }\end{array}$ & $\frac{11 ; 33.2 \pm 1.61}{30.2-36.6}$ & $1 ; 35.3$ & $1 ; 31.0$ & $\frac{4 ; 33.1 \pm 0.71}{32.5-34.1}$ & $\frac{47 ; 28.2}{24.5-31.0}$ & $5 ; 29.2$ & $\frac{10 ; 31.4}{30.0-33.5}$ \\
\hline $\begin{array}{l}\text { 13. Distal minimal } \\
\text { depth of the lateral } \\
\text { condyle }\end{array}$ & $\frac{11 ; 27.1 \pm 1.34}{25.3-30.3}$ & $1 ; 28.0$ & $1 ; 25.4$ & $\frac{4 ; 26.7 \pm 0.59}{26.0-27.4}$ & - & $5 ; 24.2$ & $\frac{4 ; 24.5}{23.5-25.0}$ \\
\hline $\begin{array}{l}\text { 14. Distal maximal } \\
\text { depth of medial } \\
\text { condyle }\end{array}$ & $\frac{11 ; 29.6 \pm 1.57}{27.2-33.3}$ & $1 ; 29.8$ & $1 ; 27.7$ & $\frac{4 ; 29.2 \pm 1.12}{27.7-30.1}$ & - & $5 ; 26.9$ & $\frac{10 ; 28.2}{27.0-30.5}$ \\
\hline
\end{tabular}


Appendix IV. Measurements of third metatarsal bones of small equid from Western Siberia (n; Mean \pm st. dev. / Min-Max) and comparative material on E. hydruntinus from Crimea and E. h. hemionus (n; Mean / Min-Max or n; Mean), mm

\begin{tabular}{|c|c|c|c|c|c|c|}
\hline \multirow[b]{2}{*}{ Measurement } & \multicolumn{3}{|c|}{ Small equid } & \multicolumn{2}{|c|}{ E. hydruntinus } & \multirow[b]{2}{*}{$\begin{array}{l}\text { E. h. hemi- } \\
\text { onus } \\
\text { (V. Eisen- } \\
\text { mann, } \\
\text { online data) }\end{array}$} \\
\hline & $\begin{array}{l}\text { Hyena's Den } \\
\text { Cave }\end{array}$ & $\begin{array}{l}\text { Oklad- } \\
\text { nikova cave }\end{array}$ & Taradanovo & $\begin{array}{c}\text { Crimea } \\
\text { (Kuzmina, } \\
1997)\end{array}$ & $\begin{array}{c}\text { Emine- } \\
\text { Bair- } \\
\text { Khosar (van } \\
\text { Asperen et } \\
\text { al., 2011) }\end{array}$ & \\
\hline 1. Maximal length & $\frac{7 ; 270.8 \pm 3.28}{265.4-275.2}$ & - & $\begin{array}{c}2 ; 267.0 \\
275.4\end{array}$ & $\frac{12 ; 251.2}{236.7-258.5}$ & $8 ; 253.5$ & $\frac{10 ; 266.8}{253.0-277.0}$ \\
\hline $\begin{array}{l}\text { 3. Minimal breadth of } \\
\text { the diaphysis }\end{array}$ & $\frac{7 ; 31.8 \pm 1.56}{29.0-33.2}$ & - & $\begin{array}{c}2 ; 30.8 \\
30.9\end{array}$ & $\frac{19 ; 25.5}{23.6-27.5}$ & $8 ; 27.1$ & $\frac{10 ; 26.0}{22.9-28.0}$ \\
\hline $\begin{array}{l}\text { 4. Depth of the } \\
\text { diaphysis }\end{array}$ & $\frac{7 ; 32.0 \pm 1.64}{29.3-34.0}$ & - & $\begin{array}{c}2 ; 31.4 \\
33.2\end{array}$ & $\frac{19 ; 25.7}{23.0-27.0}$ & $8 ; 27.2$ & $\frac{9 ; 26.1}{25.0-28.0}$ \\
\hline $\begin{array}{l}\text { 5. Proximal articular } \\
\text { breadth }\end{array}$ & $\frac{7 ; 45.0 \pm 1.19}{42.8-46.2}$ & - & $\begin{array}{c}2 ; 46.9 \\
49.4\end{array}$ & $\frac{37 ; 40.5}{38.0-43.2}$ & $8 ; 41.9$ & $\frac{10 ; 41.9}{39.0-45.0}$ \\
\hline $\begin{array}{l}\text { 6. Proximal articular } \\
\text { depth }\end{array}$ & $\frac{7 ; 40.1 \pm 1.63}{37.1-42.5}$ & - & $\begin{array}{c}2 ; 40.2 \\
43.7\end{array}$ & $\begin{array}{c}34 ; 36.1 \\
33.0-40.3\end{array}$ & $8 ; 37.1$ & $\frac{10 ; 37.0}{36.0-39.0}$ \\
\hline $\begin{array}{l}\text { 7. Maximal diameter } \\
\text { of the articular facet } \\
\text { for the third tarsal } \\
\text { bone }\end{array}$ & $\frac{7 ; 41.6 \pm 1.19}{39.4-43.0}$ & - & $\begin{array}{c}2 ; 43.7 \\
44.0\end{array}$ & - & $8 ; 37.6$ & $\frac{10 ; 38.0}{35.0-40.0}$ \\
\hline $\begin{array}{l}\text { 8. Diameter of the } \\
\text { articular facet for the } \\
\text { fourth tarsal bone }\end{array}$ & $\frac{5 ; 11.6 \pm 1.15}{10.2-12.8}$ & - & $\begin{array}{c}2 ; 12.1 \\
12.8\end{array}$ & - & $8 ; 9.6$ & $\frac{10 ; 9.7}{7.5-11.0}$ \\
\hline $\begin{array}{l}\text { 10. Distal maximal } \\
\text { supra-articular breadth }\end{array}$ & $\frac{12 ; 44.2 \pm 1.54}{41.0-46.5}$ & - & $\frac{4 ; 43.4 \pm 1.11}{39.5-45.5}$ & - & $8 ; 39.2$ & $\frac{10 ; 38.2}{35.0-40.0}$ \\
\hline $\begin{array}{l}\text { 11. Distal maximal } \\
\text { articular breadth }\end{array}$ & $\frac{11 ; 44.2 \pm 1.33}{42.8-47.4}$ & $2 ; 42.5 ; 46.3$ & $\frac{4 ; 44.3 \pm 0.85}{42.0-46.3}$ & $\frac{21 ; 37.6}{34.0-41.3}$ & $8 ; 38.1$ & $\frac{10 ; 38.9}{35.1-41.1}$ \\
\hline $\begin{array}{l}\text { 12. Distal maximal } \\
\text { depth of the keel }\end{array}$ & $\frac{12 ; 34.1 \pm 0.94}{32.8-36.0}$ & $2 ; 34.0 ; 34.0$ & $\frac{4 ; 33.5 \pm 0.97}{31.4-36.6}$ & $\frac{21 ; 29.0}{25.0-32.0}$ & $8 ; 29.9$ & $\frac{10 ; 31.7}{30.0-34.0}$ \\
\hline $\begin{array}{l}\text { 13. Distal minimal } \\
\text { depth of the lateral } \\
\text { condyle }\end{array}$ & $\frac{11 ; 26.7 \pm 0.98}{25.2-28.7}$ & $2 ; 25.5 ; 25.8$ & $\frac{4 ; 26.1 \pm 0.67}{24.4-28.4}$ & - & $8 ; 23.8$ & $\frac{4 ; 23.9}{23.1-24.5}$ \\
\hline $\begin{array}{l}\text { 14. Distal maximal } \\
\text { depth of medial } \\
\text { condyle }\end{array}$ & $\frac{11 ; 29.8 \pm 1.04}{28.2-31.3}$ & $2 ; 26.6 ; 29.0$ & $\frac{4 ; 28.7 \pm 0.93}{26.6-31.8}$ & - & $8 ; 26.1$ & $\frac{10 ; 27.8}{26.5-30.0}$ \\
\hline
\end{tabular}

Appendix V. Factor loadings for the variables in principal component analysis on metacarpal bones

\begin{tabular}{|c|c|c|}
\hline Variable & PC1 & PC2 \\
\hline 1 & -0.42 & -0.87 \\
3 & -0.95 & 0.08 \\
4 & -0.81 & -0.21 \\
5 & -0.82 & 0.19 \\
6 & -0.93 & -0.06 \\
7 & -0.92 & 0.04 \\
8 & -0.80 & 0.24 \\
10 & -0.96 & 0.16 \\
11 & -0.95 & 0.18 \\
12 & -0.95 & 0.03 \\
13 & -0.93 & -0.09 \\
14 & -0.94 & -0.15 \\
Expl.Var., \% & 77.1 & 08.03 .15 \\
\hline
\end{tabular}


Appendix VI. Results for Mann-Whitney test on metacarpal and metatarsal bones between small (mean $\left.{ }^{1}\right)$ and large $\left(\right.$ mean $\left.^{2}\right)$ equids from Kurtak

\begin{tabular}{|c|c|c|c|c|c|c|}
\hline \multirow{2}{*}{ Measurement } & \multicolumn{3}{|c|}{ metacarpal III $^{\text {metatarsal III }}$} \\
\cline { 2 - 7 } & mean $^{1}$ & mean $^{2}$ & $\mathrm{p}$ & mean $^{1}$ & mean $^{2}$ & $\mathrm{p}$ \\
\hline 1 & 226.4 & 228.1 & 0.567 & 261.3 & 272.6 & 0.01 \\
3 & 29.1 & 37.4 & $<0.01$ & 27.7 & 36.2 & $<0.01$ \\
4 & 23.6 & 26.9 & $<0.01$ & 28.9 & 33.7 & $<0.01$ \\
5 & 42.9 & 52.7 & $<0.01$ & 41.3 & 54.3 & $<0.01$ \\
6 & 28.6 & 32.9 & $<0.01$ & 35.9 & 45.4 & $<0.01$ \\
7 & 36.1 & 42.0 & $<0.01$ & 38.1 & 47.6 & $<0.01$ \\
8 & 13.0 & 16.7 & $<0.01$ & 10.0 & 13.1 & $<0.01$ \\
10 & 40.6 & 50.3 & $<0.01$ & 39.8 & 52.0 & $<0.01$ \\
11 & 40.2 & 51.0 & $<0.01$ & 40.0 & 52.9 & $<0.01$ \\
12 & 30.8 & 37.8 & $<0.01$ & 30.8 & 40.0 & $<0.01$ \\
13 & 24.8 & 29.5 & $<0.01$ & 24.1 & 30.8 & $<0.01$ \\
14 & 27.2 & 31.4 & $<0.01$ & 27.5 & 33.4 & $<0.01$ \\
\hline
\end{tabular}

